\title{
DILEMMA PERILAKU KONSUMTIF DALAM PERANNYA MEMBANGUN BISNIS RITEL MODERN DI INDONESIA \\ Oktafalia Marisa
}

Email: omuzammil@,bundamulia.ac.id

\section{Penulis}

Oktafalia, adalah pengajar tetap di Universitas Bunda Mulia dengan bidang peminatan pada rumpun kuantitatif, Keuangan dan mata kuliah perbankan

\section{Abstract}

Discount promotion in the retail industry has great charm to consumers. We can find this program in every single modern retail industry. In the past, big sale program or discount promotion could only be found find in midyear term or at the end of the year. Nowadays, the discount promotion is offered in each month. It's a unique strategy for modern retail. Matahari dept. store, as an example, has decided to use this strategy the result is the significant raise of their income. This offer is based on research about the habit of our Indonesian society in general. It's called consumptive behavior. Although in basic theory it's a well-known fact that becoming a consumptive person is not an option for in this society; in reality, the behavior saved a retail industry.

Key Words

Economic Policy, Minimum Wage, Income

\section{PENDAHULUAN}




\section{Latar Belakang Masalah}

Perkembangan pola hidup yang konsumtif di masyarakat seringkali dianggap hal yang kontra produktif. Konsumtif, kata ini sangat dekat artinya dengan pemborosan, beberapa mengartikannya dengan tindakan konsumsi barang atau jasa dengan secara berlebihan dimana keinginan menjadi prioritas dibandingkan dengan kebutuhan. Singkatnya pola hidup konsumtif sudah seharusnya dihindari dengan pengendalian diri untuk tidak terpancing mengikuti keinginan hati untuk mengkonsumsi sesuatu karena gengsi belaka. Pola hidup ini biasanya rentan terbentuk di usia remaja terutama di ibukota, alasannya simpel saja, remaja seringkali terbujuk oleh iklan, lingkungan, gaya hidup sekitarnya - tidak mau kalah dari temannya dan kurang realistis. Hal - hal yang disebutkan diatas kemudian menjadi permakluman atas fakta bahwa remaja rentan sekali menjadi konsumtif, terutama mereka yang sedang dalam peralihan mencari jati diri. Data juga menunjukkan tidak hanya remaja yang kerapkali berperilaku semacam ini, mereka yang sudah dalam tahap dewasa pun tampaknya tidak lepas dari jeratan perilaku konsumtif. Namun apabila kita melihat pola hidup masyarakat ibukota yang konsumtif tersebut pernahkah terpikir bahwa pola hidup semacam ini tidak sepenuhnya keliru, tidak sepenuhnya berdampak negatif. Pola hidup seperti ini disadari atau tidak sebenarnya turut menggulirkan roda perekonomian, saya memilih kata 'menggulirkan' alih alih 'membangun' roda perekonomian bukan tanpa sebab, melainkan dari beberapa pengamatan dan observasi mengenai hal ini. Pola hidup konsumtif menurut observasi ternyata menghadirkan dampak dengan dua sisi mata uang, dampak negatif dari pola hidup semacam ini mungkin tidak pertanyakan kembali, namun ada sisi positif dalam perilaku masyarakat konsumtif yang mungkin sudah agak menjurus ke perilaku gaya hidup hedonis.

Dampak positif yang dimaksud tentunya pergerakkan atau bergulirnya roda perekonomian, sederhana saja bila ada permintaan tentunya akan mendorong produksi, menciptakan penjualan, menghasilkan pendapatan, upah dan kemudian pada akhirnya kembali mendorong konsumsi begitu seterusnya yang terjadi. Bisa dibayangkan, tidak ada permintaan tentu tidak ada pembelian. As simple as that. 
Artikel penelitian ini saya susun berangkat dari hal yang sederhana tersebut, yang secara sadar atau tidak telah menyelamatkan beberapa bisnis dari keterpurukan akibat menurunnya permintaan secara drastis. Dalam penelitian ini yang menjadi objek penelitian adalah dunia ritel modern indonesia. Industri ritel terpilih menjadi objek penelitian dikarenakan industri ini berkembang sangat pesat, namun berdasarkan penelitian yang sudah ada sebelumnya industri ritel sendiri merupakan industri yang amat rentan terhadap krisis, rentan terhadap tipisnya marjin bahkan untuk beberapa jenis usaha ritel seperti mini market dan sejenisnya atau yang kenal dengan modern market kerapkali menjadi objek yang dikambinghitamkan, singkatnya objek protes dari para pelaku tradisional market. Meski demikian nyatanya hal ini tidak menyurutkan kekuatan ritel untuk terus berkembang dengan pesat di Indonesia. Data terakhir dari BPS menyatakan bahwa dunia ritel indonesia telah berkembang pesat dalam dua tahun terakhir, dan meraih 9,3 persen pertumbuhan pada kuartal pertama tahun 2010. Tercatat pula dalam menghadapi krisis global 2007 yang lalu dunia ritel Indonesia mampu bertahan dengan baik.

\section{Rumusan Masalah}

Kembali mengenai pokok permasalahan penelitian dari Fakta - fakta menarik ritel tersebut dan dengan menghubungkan pola perilaku konsumtif masyarakat metropolitan maka saya tertarik untuk mengembangkan suatu penelitian dengan tajuk "Dilemma Perilaku Konsumtif dalam Perannya Membangun Bisnis Ritel Modern di Indonesia".

\section{PEMBAHASAN MASALAH}

Ada satu fenomena yang cukup unik di masyarakat saat ini, disaat perekonomian secara global, tidak hanya di Indonesia sedang mengalami guncangan hebat akibat krisis global 2007, terbentuk suatu kultur baru, budaya yang baru yaitu budaya Great Sale. Saat ini semakin sering kita jumpai industri ritel khususnya di mall - mall besar menggelar perhelatan yang berhubungan dengan diskon ataupun cuci gudang demi menarik konsumen yang ada, untuk dapat menikmati diskon atau potongan harga di mall mall 
tersebut tidak perlu lagi menunggu akhir tahun atau yang kita kenal sebagai year end sale, cukup datangi mall terdekat dan tampaklah budaya diskon tersebut, entah dalam gelaran week end sale, midnite sale, bahkan tidak kalah dengan negara tetangga yang terlebih dahulu memiliki program wisata belanja, seperti Singapore Great Sale yang fenomenal tersebut, Indonesia juga punya satu ajang diskon besar-besaran, dimana tahun ini tercatat 33 mall besar di ibukota dan sekitarnya secara bersamaan menggelar satu ajang yang biasa dikenal dengan Jakarta Great Sale, Sale serempak selama satu bulan penuh untuk menyambut ulang tahun kota Jakarta. Ajang ini sebenarnya bukan ajang yang baru, namun setiap tahun terlihat usaha dan perbaikan dari penyelenggara event ini untuk kemudian membuat acara ini semakin meriah. Hal ini tentunya bukan tanpa alasan, untuk apa dunia ritel begitu gegap gempita untuk menyelenggarakannya, bahkan pemerintah rupanya tidak ingin ketinggalan. Pemerintah melalui Gubernur DKI Jakarta, Fauzi Bowo sendirilah yang meresmikan gelaran ini secara meriah tidak hanya gubernur, KADIN Jaya dan berbagai asosiasi perdagangan. Asosiasi perdagangan ini meliputi Asosiasi Pusat Belanja Indonesia (APPBI), Asosiasi Pengusaha Ritel Indonesia (APRINDO), Persatuan Hotel \& Restaurant Indonesia (PHRI), Asosiasi Rekreasi Keluarga Indonesia (ARKI), Asosiasi Perancang Pengusaha Mode Indonesia (APPMI), Asosiasi Matahari Suppliers Club (AMSC), Asosiasi Persepatuan Indonesia (APRISINDO), dan Asosiasi Media Luar Indonesia (AMLI). Selain itu ada Perusahaan Kosmetik Indonesia (PERKOSMI), Asosiasi Pengusaha Pemasok Pasar Modern Indonesia (AP3MI), Asosiasi Indonesia Travel Agent (ASITA), Asosiasi Spa Indonesia (ASPI), dan PD Pasar Jaya ikut serta bekerja sama untuk memeriahkan gelaran akbar 2010 ini. Sebenarnya apa yang dituju baik pemerintah maupun pengusaha ritel dalam hal ini?

Menjawab pertanyaan diatas tentunya akan sangat menarik, kultur bangsa Indonesia di akui atau tidak mengarah ke arah pola hidup konsumtif. Penampilan luar seringkali menjadi segalanya, kultur tidak ingin kalah dari lingkungan sekitarnya semakin mendorong pola hidup konsumtif tersebut. Meski sulit secara ekonomi atau kata lainnya pas-pasan, tidak sedikit masyrakat yang memaksakan diri untuk tetap berpenampilan 
yang "waw" sekedar menyaingi orang-orang di sekitarnya tersebut tadi, meskipun hal ini memaksa yang bersangkutan harus sedikit lebih membatasi pengeluaran yang lainnya, demi penampilan hal tersebut menjadi wajar saja dan rela untuk dilakukan. Itulah mengapa terkadang kita masih bisa terheran - heran melihat gegap gempita kemilaunya metropolitan, sementara angka HDI (Human Development Index) Indonesia, yaitu indeks yang melihat tingkat kesejahteraan masyarakat Indonesia maupun tingkat pendapatan perkapita Indonesia, yaitu besarnya pendapatan rata-rata penduduk di suatu negara dimana pendapatan perkapita ini didapatkan dari hasil pembagian pendapatan nasional suatu negara dengan jumlah penduduk negara tersebut, masih relatif rendah namun tingkat konsumsi non pangan masih relatif tinggi. Hal ini tentunya tidak terlewat begitu saja bagi pebisnis di dunia ritel modern Indonesia. Ini adalah suatu peluang yang menarik, tidak hanya untuk bertahan dalam persaingan, namun juga mengeruk keuntungan. Dunia ritel ini tentunya bukanlah dunia yang $100 \%$ anti guncangan penurunan pendapatan atau penjualan, pendapatan bisa saja turun, keadaan perekonomian yang tidak baik tentunya berperan dalam menurunkan tingkat penjualan tersebut, namun ternyata ada yang masih dapat dilakukan para pelaku ritel indonesia, pancing sedikit masyarakat dengan imingiming diskon, potongan harga atau promosi lainnya untuk meningkatkan pembelian, hasilnya ternyata masyarakat indonesia akan merespon hal tersebut dengan baik, meskipun yang dibeli kemudian bukan merupakan kebutuhan pokok dalam kehidupannya, konsumtif. Ya, demikianlah kultur masyarakat Indoneia terbentuk dan berkembang dengan suburnya.

Win-win solution, mungkin inilah yang kemudian menjadi alasan terjadinya sinergi yang efektif oleh pemerintah dan pelaku bisnis ritel dan juga masyarakat Indonesia sendiri tentunya. Untuk pemerintah gelaran Jakarta Great Sale (JGS) adalah upaya untuk mempromosikan produk dalam negeri, mempromosikan wisata dan mencegah larinya capital flight ke negara tetangga kita seperti Malaysia atau pun Singapura karena ironisnya meskipun pendapatan per kapita Indonesia di bawah ke dua negara tersebut ternyata pembelanja tertinggi di kedua negara tersebut ternyata masih di dominasi oleh Warga Negara Indonesia (WNI). Hal ini tentunya menjadi sesuatu yang perlu untuk di soroti, betapa tidak ternyata penyumbang pendapatan bagi ke dua negara 
terebut adalah masyarakat dari negara kita tercinta ini. Pertanyaan tentu mucul menanggapi hal ini. Kenapa masyarakat Indonesia begitu bersemangat untuk membelanjakan uangnya di negeri orang daripada di dalam negeri padahal kualitas produk tidak beda jauh, bahkan kapasitas mall nya sendiri tidak beda jauh dari di Indonesia, bahkan mungkin Indonesia memiliki fasilitas mall yang lebih besar dan lebih banyak dalam jumlah kuantitas, lalu apa alasanya hal itu terjadia, survey kecil yang saya lakukan terhadap pembelanja pada Singapore Great Sale tahun lalu, memberikan indikasi yang menjawab pertanyaan tersebut, pada gelaran pesta diskon di negara tetangga kita tersebut diberikan diskon diskon lebih dalam hal pembebasan pajak atau $\operatorname{tax}$, mereka memberlakukan tax refund di bandara internasional bagi para pembelanja di gelaran tersebut, suasana berbelanja ternyata sangat terasa pada gelaran tersebut, singkatnya belanja pada Singapore Great Sale memberikan suatu experience tersendiri, terutama event belanja tengah malam atau midnite sale memberikan suasana yang priceless -meskipun saat ini sudah banyak pusat perbelanjaan modern Indonesia yang menyelenggarakan hal serupa namun Singapore lah pelopornya di Asia Tenggara, belum lagi kalau kita membandingkan games-games menarik yang di hadirkan untuk menghibur para pembelanja dan menyemarakkan event tersebut, hal menarik lainnya ternyata gelaran ini mampu menyatukan para pengelola pusat perbelanjaan di Singapore, meski berbeda manajemen namun mereka bekerja sama dengan amat baik, bila anda kehabisan stock yang diinginkan di tempat perbelanjaan tersebut, tidak perlu menunggu lama anda akan diberikan informasi mengenai di mana anda bisa mendapatkan barang tersebut, yang memberikan informasi kebanyakan adalah concierge dari mall tersebut, bukan pramuniaga outlet dari distributor yang tentunya hanya merujuk pada outlet mereka yang lainnya bukan dalam kapasitas mall, bandingkan dengan yang terjadi di Indonesia, antar cabang outlet saja terkadang malas atau missed dalam memberikan informasi. Bukti lainnya adalah di negara tetangga tersebut, akses mall to mall disatukan oleh stasiun MRT artinya pintu antar mall terbuka satu sama lain. Kerjasama juga tidak terbentuk, contohnya pada gelaran Jakarta Great Sale yang lalu saja, pusat perbelanjaan yang turut serta hanyalah pusat perbelanjaan yang dikelola oleh Podomoro Group, lainnya tidak 
dengan alasan bukan satu manajemen. Bahkan akses keluar masuk mall di Jakarta yang notabene berseberangan jalan pun tidak akan tercipta dengan alasan yang sama.

Last but not least, gelaran Singapore Great Sale didukung penuh oleh kerjasama pemerintah, pihak retail modern setempat sampai dengan bidang kepariwisataan dan sektor swasta lainnya, contoh kecil perusahaan airlines dari negara tersebut turut serta menopang helatan Singapore Great Sale dengan cara memberikan paket harga yang menarik dalam pekan Singapore Great Sale tidak hanya jasa penerbangan, hotel hotel setempat juga berlomba memberikan rate menarik dalam acara tersebut, bandingkan hal ini dengan fakta bahwa departemen pariwisata Indonesia sempat tidak tahu menahu mengenai gelaran Jakarta Great Sale. Berbagai aksi mendukung di negara tetangga kita tersebut, bila diperhatikan lebih seksama ternyata memang di tujukan untuk turis asing, khususnya Wisataman dari Indonesia, daripada warga lokal sendiri. Hal ini tentunya adalah fakta unik, bahwa pemerintahan Singapore menyadari bahwa Warga Negara Indonesia merupakan objek penghasil keuntungan bagi negaranya melalui aksi belanja masyarakat Indonesia tersebut.

Langkah pemerintah Indonesia tidak bisa dikatakan gagal, lihat saja dari hasil penyelenggaraan Jakarta Great Sale yang melampaui target Rp. 7.000.000.000.000,angka yang fantastis untuk transaksi selama satu bulan di tengah masyarakat yang katanya negaranya sedang di lilit hutang berkepanjangan sampai dengan anak cucunya nanti. Pesona diskon di ritel modern Indonesia telah terbukti nyata. Bila dikembalikan ke awal artikel hal ini tentu nya tidak terjadi begitu saja namun ada akar pola hidup masyarakat konsumtif yang menyuksekan gelaran Jakarta Great Sale, tidak hanya event ini yang sukses, pusat perbelanjaan seakan - akan ketagihan membuat program diskon bahkan midnite sale yang dulu langka menjadi jadwal rutin yang terkirim melalui layanan messenger, seperti bbm atau jejaring sosial lainnya. Program seperti ini terbukti menarik dan menggerakkan roda perekonomian yang awalnya agak tersendat bagi para pengusaha ritel. Apakah sebetulnya keistimewaan midnite sale dibanding sale lainnya. Sebenarnya nyaris tidak ada keistimewaan, mungkin perbedaanya adalah periode berbelanjanya saja yang bergeser, diskon yang di berikan hanya berlaku dari jam 8 malam sampai tengah malam. Barang-barang yang di-sale pun bukan barang-barang baru tentunya, stok lama 
yang diambil dari gudang. Namun ternyata ada satu hal yang didapat konsumen yaitu sebuah experience yang berbeda yang menjadikan tradisi berbelanja tidak hanya untuk para wanita saja namun seluruh keluarga, ada hiburan yang didapat dari kegiatan semacam ini bagi para keluarga dan para pembelanja lainnya.

Adalah Dabenhams, departemen store di Senayan City yang pertama kali melakukannya di tahun 2008. Kala itu animo masyarakat terhadap acara itu sangat besar. Midnight Sale yang dimaksud hanya memperpanjang waktu buka, yang biasanya buka sampai jam 10 malam diperpanjang hingga pas tengah malam. Lucunya kala itu masyarakat banyak membeli bantal dan guling karena bantal guling yang harga normalnya ratusan ribu di-sale jadi cuma $\mathrm{Rp} 90.000$,- saja, apakah ini kebutuhan atau keinginan yang menjadi akar pola hidup konsumtif? Anda yang berhak menjawabnya, tapi terlepas dari hal itu ada hal penting lainnya yang tercapai. Ada peningkatarı penjualan disana, peningkatan income, tingkat produksi pun punya harapan meningkat, yang diterjemahkan secara singkat dengan bergeraknya roda perekonomian, hukum ekonomi pun berlaku, ada permintaan maka akan menciptakan penawaran. Tingkat keuntungan yang dicatatkan oleh Dabenhams pun tidak main main, dari 13.000 pengunjung midnite sale pertama kalinya di Indonesia ini tercatat kenaikan angka penjualan hingga dua kali karena pengaruh midnite sale ini. Bahkan pihak Mitra Adi Perkasa sebagai pemegang hak Dabenhams mengakui berkat acara tersebut, unit departmen store bisa mengontribusi keuntungan perusahaan hingga $45 \%$, sebagian besar dipengaruhi oleh angka penjualan Dabenhams yang cukup besar dari promo Midnite Sale.

Mengulang sukses tersebut, Senayan City kembali menggelar acara serupa bahkan dengan lebih meriah dan diikuti oleh $70 \%$ tenant yang ada. Jika tahun ini Dabenhams, selaku salah satu tenant pelopor acara ini menawarkan promo buy 1 get 1 free, tenant lainnya, seperti Best Denki menawarkan lucky draw satu unit kendaraan setiap jamnya. Ada juga beberapa merek yang menawarkan promo potongan harga hingga lebih dari $70 \%$ seperti misalnya Banana Republic, Guess Boutique, C\&F Perfumery, Nina MG, dan masih banyak lagi. Tentu saja fenomena ini memberikan keuntungan finansial pada masing-masing tenant di Senayan city. 
Menurut observasi, Ada beberapa faktor yang memengaruhi konsumen berburu midnite sale. Selain ingin membeli pakaian sebagai pemenuhan gaya hidup metropolitan, ternyata potongan harga yang diberikan juga bukan hanya sekadar isapan jempol belaka. Keberhasilan Senayan City kemudian diikuti oleh Pondok Indah Mall, Grand Indonesia, Mal Taman Anggrek, Supermal Karawaci, Pejaten Village, Emporium Pluit Mall, Mal Kelapa Gading kemudian menjalar ke Bandung. Istilahnya bisa beragam dari Midnight Shopping, Late Night Shopping, Super Midnight Sale hingga Night Salebration. Contoh lainnya dari peritel modern Indonesia yang taktis dalam menjalankan jurus diskon dan potongan harga adalah Matahari Dept Store, perusahaan dibawah naungan PT Matahari Putra Prima ini sempat mengalami kerugian besar di tahun 2008. Namun strategi penjualannya, termasuk dengan menggelar berbagai diskon dan bahkan cash back telah mengubah kerugian di tahun yang lalu tersebut menjadi pencapaian profit gemilang di tahun 2009 dan paruh pertama 2010, penyebabnya apalagi kalo bukan kenaikan tingkat penjualan secara signifikan dari program diskon yang diadakan oleh yang bersangkutan, padahal program cash back yang diadakan oleh peritel ini seyogyangya malah membuat konsumen tergerak untuk kembali menghabiskan uangnya untuk membeli sesuatu yang mungkin tidak di butuhkan, dengan cerdiknya departemen store ini mengadakan suatu program potongan belanja sebesar $\mathrm{Rp} 50.000$,- setiap pembelanjaan minimal Rp 150.000 ,- tidak berlaku kelipatan. Potongan harga ini hanya bisa dipakai pada hari itu juga, artinya konsumen tidak diberikan kesempatan untuk terlalu lama berfikir, bahkan ada syarat tambahan, promosi ini hanya dapat di gunakan bagi produk dengan lambang khusus dengan ketentuan setelah di potong voucher cash back adalah nilai belanjanya adalah minimal sebesar Rp 100.000,-. Strategi menarik dan efektif, karena dari pengamatan dan data yang dikumpulkan selama periode penulisan makalah ini 6 dari 10 penerima voucher memanfaatkan voucher tersebut, dengan alasan daripada mubazir lebih baik dibelanjakan kebutuhan yang 'mungkin' terjadi di kemudian hari, dengan kata lain pembelian tersebut adalah pembelian impulsif, pembelian di luar rencana dan bahkan tidak mendesak paling tidak sampai dengan saat pembelian tersebut dilakukan dimana hal terebut dilakuakan konsumen dengan keadaran penuh tanpa paksaan dari pihak manapun 
Apa yang dilakuan oleh Matahari Dept. Store tersebut, bukanlah sesuatu yang ilegal. Bahkan petugas kasir yang ada turut memberikan penjelasan mengenai syarat penggunaan cash back tersebut, jadi tidak ada unsur penipuan atau akal-akalan disini. Keputusan akhir tetap ditangan konsumen sendiri, dan bukan tanggung jawab mereka atas sikap konsumtif para konsumen. Mereka menjalankan strategi dengan baik, tidak hanya dalam konteks profit saja, keuntungan yang diraih membuat Matahari Dept Store mampu untuk menampung tenaga kerja tambahan di cabang-cabangnya di seantero tanah air seiring dengan pembukaan outlet/cabang baru oleh perusahaan ini, tentunya peluang menarik bagi angkatan kerja Indonesia yang belum memperoleh pekerjaan. Setidaknya hal ini kemudian akan sedikit membantu meringankan beban masyarakat dan juga pemerintah terutama dalam mengatasi persoalan pengangguran tentunya.

Contoh lainnya adalah hal yang diraih oleh Ace Hardware, gelaran midnite sale dimanfaatkan Ace Hardware, peritel perlengkapan rumah tangga, untuk mendongkrak penjualan di tengah lesunya bisnis ritel di awal 2009 yang lalu. Adalah awal Mei 2009 ketika perusahaan ritel ini menggelar midnite sale pertama kalinya. Para pengunjung antusias, bahkan para pengujung tersebut rela berdesak-desakan menantikan pukul 21.00 malam sebagai jam resmi dibukanya ajang diskon sampai tengah malam oleh pihak manajemen Ace Hardware. Pantas saja mereka mau berjejalan datang. Karena diskon yang ditawarkan juga tidak main-main. Mulai dari $10 \%$ sampai $70 \%$. Tak hanya di satu cabang Ace Hardware, pihak Ace Hardware juga menggelar diskon tengah malam serupa di Ace Hardware Cibubur dan Ace Hardware Puri Mall. Hasilnya sungguh tak disangka. Menurut Imelda Widjaja, Investor Relation Ace Hardware, rata-rata di ketiga toko yang menggelar diskon tengah malam tersebut, pengunjungnya membeludak sampai dua kali lipat dari hari biasanya. Tak heran jika omzet penjualan di ketiga toko tersebut juga terkerek naik sampai dua kali lipat. Sebuah angka yang menarik bagi perkembangan bisnis ritel dan roda perekonomian Indonesia. Dari pelaksanaan diskon tengah malam tersebut ada hasil yang signifikan bagi Ace Hardware untuk mendongkrak penjualan yang belakangan lesu. Tengok saja hasil laporan keuangan perusahaan ini yang menyebutkan proyeksi penjualan tahun ini hanya tumbuh $20 \%$ saja atau sekitar Rp1,53 triliun. Sementara tahun 2008 lalu tumbuh $44,3 \%$ atau sebesar Rp1,28 triliun. Namun 
dengan adanya keberhasilan program ini, paling tidak ada pihak-pihak yang dapat menikmati ketenangan, pimpinan perusahaan dan pemegang saham sudah tentu, namun yang paling penting adalah para pekerja di perusahaan tersebut. Mereka akan mendapatkan titik cerah mengenai keberlangsungan pekerjaan mereka di perusahaan tersebut bila perusahaan dapat tumbuh, berkembang serta dan mencatatkan laba dengan baik sesuai yang diharapkan.

Setelah beberapa fakta sukses penyelenggaran promo great sale tanah air yang diungkapkan diatas, ada baiknya kita mengamati fenomena great sale dan midnite sale serta dampaknya di negara asalnya. Di Tanah Seberang, fenomena ini bukanlah hal yang baru. Di Amerika Serikat hal serupa ini terjadi setiap akhir tahun, yaitu satu hari setelah Thanksgiving yang telah dimulai pada tahun 1960-an. Sebagai perbandingan bagaimana mereka menjalankan roda bisnis, mari kita tengok secara langsung kegiatan serupa di tanah air ini. Adalah sebuah event bertajuk Black Friday, yaitu gelaran pesta diskon besar-besaran oleh para peritel yang diadakan sehari setelah Thanksgiving tepatnya di wilayah California Utara, masyarakat di sekitar sedari subuh sudah mengantri di depan toko-toko ritel untuk berbelanja, bahkan ada yang sampai mendirikan tenda dari tengah malam, dan sewaktu toko-toko tersebut akhirnya dibuka maka seperti kerasukan setan mereka berlari masuk ke toko, mencari dan "merampas" barang yang akan dibeli. Dalam kondisi seperti ini, juga pernah terjadi saling berebutan barang dangangan dan pertikaian. Sebagai gambaran betapa ramai dan hiruk-pikuknya penjulan pada hari seperti ini, pernah dilaporkan bahwa pada perhelatan Black Friday 28 November 2008 seorang karyawan dari Wal-Mart, jaringan retailer terbesar di dunia dari Amerika Serikat, terinjak-injak di antara ratusan pengunjung sampai meninggal pada jam 5 pagi. Tentu tragedi seperti ini harus dihindarkan terjadi di Tanah Air.

Tragedi itu tidak sampai menghentikan ataupun mengubah tradisi Black Friday di California Utara, hal ini karena kemudian pemerintah telah menginstruksikan agar sisi keamanan lebih diperhatikan di tambah lagi tidak ada pihak yang repot-repot menjadikan isu ini sebagai upaya memprotes pemerintah yang sebenarnya dilakukan hanya untuk kepentingan politik seperti yang terjadi di tanah air. Semua pihak menyadari bahwa ternyata transaksi-transaksi yang terjadi pada Black Friday telah menghidupkan sendi 
perekonomian masyarakat sekitar. Fakta yang terungkap pada hari seperti itulah, seorang pelanggan akan mengorbankan rata-rata USD 350 untuk barang belanjaan mereka. Aku sendiri menghabiskan USD 299 untuk membeli HDD Camcorder (di Tanah Air disebut Handycam). Pada hari itulah juga, perusahaan retail mengeruk keuntungan terbesar dibandingkan dengan hari-hari lain di tahun yang sama. Setiap hari Kamis minggu ke empat bulan November, masyarakat di tanah seberang merayakan hari Thanksgiving, yaitu hari yang diasosiasikan dengan pengungkapan rasa terima kasih kepada Tuhan atas keberhasilan panen mereka, walaupun secara historikal, Thanksgiving sangat kental kaitannya dengan kegiatan religi, tetapi sekarang diidentifikasikan sebagai hari libur sekular. Pada keesokan harinya, pada penyelenggaraan Black Friday, mereka secara resmi memasuki holiday season dan masa belanja untuk hadiah dan oleh-oleh bagi mereka yang dicintai, keluarga dan handai taulan. Black Friday pernah dikaitkan dengan beberapa pengertian. Pengertaian khusus yang dikaitkan dengan kesibukan belanja setelah hari Thanksgiving bisa ditelusuri paling tidak hingga tahun 1966. Dalam suatu media di Philadelphia dikatakan, Black Friday adalah nama yang diberikan oleh Polisi Philadelphia kepada hari Jum'at setelah hari Thanksgiving. Ini bukan suatu istilah yang menyenangkan dalam kaitannya dengan tugas mereka. Black Firday secara resmi memulai musim belanja Natal di pusat kota, dan biasanya mengakibatkan kemacetan total dan keramaian yang tak terhingga di pinggir jalan di mana toko-toko dibanjiri oleh massa dari buka hingga tutupnya.Hingga kini, pada hari Black Friday, banyak orang mengambil cuti kerja sebagai bagian dari hari libur Thanksgiving. Kesempatan inilah oleh mereka yang biasanya sibuk bekerja dijadikan kesempatan untuk membeli oleh-oleh Natal. Di lain pihak, untuk menarik perhatian pelanggan, para produsen dan pemilik toko umumnya melakukan melakukan dekorasi Natal dan Tahun Baru, dan acara yang menarik di toko maupun di mal-mal. Seperti berfoto bersama dengan Sinter Klas, pengadaan kereta-keretaan untuk anak kecil, dan peragaan tarian dan nyanyian. Tujuannya adalah mengundang keluarga-keluaga untuk datang dan menghabiskan waktu bersama yang tentunya merupakan suatu added value atau experience berbelanja bagi mereka yang berbeda dengan waktu regular dimana kegiatan tersebut diselipi harapan membuncah akan diakhiri dengan kegiatan belanja bersama keluarga. 
Melihat fakta diatas tentu menarik, ternyata kesadaran peritel modern mengenai efektifitas promo berbelanja dengan diskon di negara yang maju sudah berlangsung sejak lama. Mereka tahu betul bagaimana memanfaatkan moment moment tertentu bagi para konsumen, masyarakat di belalahan dunia manapun tentunya membutuhkan hiburan atau liburan bersama, berbelanja ternyata merupakan suatu pilihan hiburan yang menarik, tentunya hal ini merupakan peluang menarik bagi para peritel terutama peritel modern karena dengan menyediakan tambahan value atau experience bagi kegiatan berbelanja masyarakat, dari secuplik fakta diatas juga, terlihat jelas meskipun warga negara Amerika Serikat tergolong tidak sekonsumtif masyarakat Indonesia ternyata mereka tetap antusias sekali dalam menyambut pesta diskon tersebut, apalagi untuk masyarakat Indonesia. Peluang ini tentu lebih terbuka lebar tentunya. Masyarakat mendapatkan hiburan yang mereka butuhkan dan tentunya masyarakat dapat berbelanja dan mendatangkan income tersendiri bagi bagi para peritel modern setempat.

Sebenarnya ada beberapa pilihan dalam mengemas suatu pesta diskon bagi para peritel seperti yang juga dilakukan oleh para peritel di negara lain, hal tersebut antara lain dengan cara memberikan diskon yang sangat murah atas barang dagangan tertentu yang disebut doorbuster. Bukan hanya sangat murah, bahkan mereka juga berani menawarkan di bawah harga pengadaan atas beberapa produk. Barang yang di bawah harga pengadaan ini disebut loss leader. Beberapa doorbuster dan loss leader - yang biasanya adalah peralatan elektornik dan mainan - inilah yang menjadi incaran dari ratusan orang yang berbaris sejak malam hari. Selain itu para peritel dapat mengiklankan barang dagangan diskon tersebut satu hari sebelumnya dengan harapan timbul rasa penasaran bagi masyarakat dan tentunya rasa 'siaga' akan kemunculan penawaran serupa di kemudian hari, dalam iklan tersebut harus disebutkan secara jelas, apa saja doorbuster dan loss leader-nya dan berapa jumlahnya. Jumlah barang tersebut bisanya sangat terbatas, dan tidak disediakan rain check (pemesanan ulang) sehingga memancing berbondong pelanggan untuk datang paling awal dan berbaris paling depan supaya bisa membeli barang tersebut.

Strategi lainnya adalah mengenai waktu berbelanja yang berbeda dari waktu operasional normal ritel-ritel tersebut. Sekali lagi hal ini berkenaan dengan experience 
berbelanja yang berbeda yang akan dialami pembelanja, suatu additional value yang tentunya priceless untuk mereka. Bisa dipilih yang paling pagi, sedari subuh atau pun yang sampai larut malam seperti gelaran midnite sale. Dengan strategi seperti itu, ternyata data menunjukkan bahwa para retailer di tanah air paling tidak berhasil menggeruk pendapatan rata-rata sebesar $18 \%$ dan untuk toko tertentu seperti penjual perhiasan, penjualannya bisa mencapai $40 \%$ dari total penjualan pertahun. Angka-angka diatas tentu menggiurkan bagi peritel dan tidak heran kalau saat ini gelaran diskon selalu berlangsung hampir tiap bulannya di berbagai pusat berbelanjaan modern di tanah air. Tidak hanya peritel ternyata yang memanfaatkan situasi konsumtif ini, ada industri lainnya yang turut serta yaitu industry perbankan melalui divisi kartu kreditnya. belakangan bila kita melihat di tiap pojokkan pusat perbelanjaan pasti terdapat booth dari kartu kredit, menawarkan kemudahan berbelanja dan pembayaran, promosi diskon berbelanja dan cash back bila menggunakan kartu kredit yang bersangkutan sampai dengan batasan limit kartu kredit yang, --well tanpa batasan. Makin konsumtif? Pasti. Inilah sebuah industri, ada pangsa pasar, ada permintaan, pastinya ada penyedia permintaan tersebut sampai dengan supporting part nya. Demikianlah yang terjadi, tidak heran kemudian syarat pembuatan kartu kredit kian mudah namun limit nya kian tinggi, sesuatu yang sebenarnya dapat membahayakan tidak hanya bagi masyarakat yang telah memiliki bakat konsumtif sampai dengan berbahaya bagi perekonomian negara sendiri. Dari pengalaman pribadi sewaktu mengikuti gelaran diskon spesial dari salah satu produk sepatu dan tas kenamaan di Senayan City beberapa waktu yang lalu, saya menjadi saksi akan hal ini. Ditengah-tengah antrian yang panjang dan lama tersebut ada satu produsen kartu yang rupanya mensponsori acara ini yang secara intens menawarkan serta membujuk konsumen untuk membuat kartu kredit dari bank tersebut, tentunya dengan segala kemudahannya. Hanya berbekal fotokopi identitas diri saja kartu tersebut sudah menjadi milik anda, tidak hanya itu kemudahan lain diberikan bagi para pemegang kartu tersebut, peminatnya? Jangan ditanyakan lagi, rata-rata konsumen tertarik lalu kemudian melakukan registrasi untuk kartu tersebut. Lagi-lagi sebuah iming-iming dengan memanfaatkan pola hidup yang konsumtif. Bahkan untuk lebih memperjelas target pasarnya, beberapa waktu yang lalu salah satu perusahaan penerbit kartu kredit dan 
perbankannya sengaja menciptakan kartu kredit khusus wanita dengan keistimewaan apalagi selain yang berhubungan dengan kegiatan berbelanja di ritel ritel modern di Indonesia. Bukti nyata lagi bahwa perilaku konsumtif tidak selamanya hal yang sia-sia, namun mampu untuk membuat suatu industry paling tidak mampu bertahan ditengah situasi yang kompetitif saat ini.

\section{KESIMPULAN}

Bisakah retailer di Tanah Air mentransformasi fenomena Midnite Sale atau Belanja Tengah Malam atau gelaran diskon lain di pusat perbelanjaan menjadi tradisi seperti di Tanah Seberang untuk kemudian memutar roda bisnis mereka lebih kencang. Paling tidak sampai dengan artikel diturunkan jawabannya adalah tentu saja bisa. Indikasinya jelas, selain data dari peritel yang sudah diutarakan diatas, bisa kita lihat peritel modern semakin sering saja menggelar acara - acara bertajuk diskon belakangan ini. Sebuah contoh nyata di mana perilaku konsumtif turut andil dalam kaitannya sebuah organisasi seperti ritel dapat bertahan di suasana pasar yang kian kompetitif saat ini. Namun tentunya strategi ini bukan tanpa kelemahan, peritel dalam mengelola bisnisnya ternyata memiliki keterbatasan dalam mengelola suatu marjin. Batas marjin yang diperoleh peritel biasanya amat tipis. Bila gelaran diskon tersebut digelar hanya pada waktu tertentu misalkan pada ulang tahun Jakarta atau yang kita kenal dengan nama Jakarta Great Sale (JGS) atau pada akhir tahun saja maka dipastikan peritel masih akan meraih keuntungan dominan, karena biasanya sale yang diadakan hanya untuk produk yang sudah memasuki end of season atau yang sudah akan diganti oleh produk dari season yang baru, tentunya dengan sale ini peritel dapat memperoleh pendapatan dari produk yang sebenarnya dinilai sudah habis tapi ternyata masih mampu menghasilkan sesuatu. Namun apabila yang terjadi seperti saat ini, dimana program great sale berlangsung hampir bulannya maka lama kelamaan akan menggerus marjin dan hanya sekedar memutar investasi peritel tanpa keuntungan untuk mengembangkan usaha. Mengutip dari bukunya yang berjudul Retail Rules, seorang ahli dan pengamat dunia ritel dari Nielsen, Yongki Susilo menyatakan bahwa, "Seharusnya membangun value, bukan 
hanya diskon. Kalau fokus pada diskon margin makin tipis". Ia menjelaskan, membangun value atau nilai bisa terus dikembangkan oleh peritel dengan kata lain aspek service atau layanan ke pelanggan menjadi hal utama. Yongky mencontohkan pengembangan value bisa dikembangkan dalam sistem delivery barang ke rumah-rumah pelanggan bagi yang berbelanja toko ritel. Masih menurut beliau, value bisa juga diberikan dalam memberikan perhatian atau follow up bagi pelanggan yang telah membeli produk. Bisa dilakukan dengan cara mengontak kembali pelanggan menanyakan produk yang telah dibelinya apakah sesuai harapan, memberikan update informasi dan lain-lain semacam after sales services. Pengembangan value atau yang pada makalah ini dibahasakan dengan nilai experience sangat penting, karena saat ini bukan tidak mungkin ada kecenderungan para konsumen justru sudah mulai mengalami kejenuhan pada aneka diskon yang ditawarkan oleh peritel, apalagi ternyata melihat konsep midnite sale yang di gelar pusat perbelanjaan tanah air ternyata menjadi hal yang kurang kreatif dari awal di perkenalkannya konsep ini, tidak ada penambahan berarti lainnya yang ditawarkan peritel tanah air, selain hanya menambah waktu operasional dan berbelanja saja tanpa detail menarik lainnya. Tidak cukup hanya gelaran diskon menggebu-gebu yang dilakukan para peritel tanah air saja yang diperlukan untuk meningkatkan pendapatan nasional dan memutar roda perekonomian, secara singkat benar adanya bahwa acara dengan tajuk seperti ini menarik konsumen untuk berbelanja, berperilaku impulsif. Namun ada beberapa hal yang patut menjadi catatan. Ritel butuh detail, ciptakanlan suasana yang memberikan experience yang berbeda bagi pembelanja, sehingga tanpa menunggu diskon mereka akan meningkatkan kunjungan yang bisa jadi berujung pada pembelian, apalagi bila mereka yang tadinya hanya ingin window shopping saja turut mengikutsertakan keluarganya, kemungkinan besar rekreasi tersebut berujung pada kegiatan belanja keluarga. Strategi penawaran yang jitu juga harus dipraktekkan oleh para prajurit ritel, yaitu pramuniaga dari ritel tersebut. Pramuniaga yang efektif adalah mereka yang mampu mengubah rencana pembelian konsumennya, dari yang sekedar melihat kemudian jadi membeli, yang tadinya membeli kemudian memutuskan membeli tambahan diluar rencananya. Hal ini amat mungkin dilakukan, apalagi dengan kultur timur yang "tidak enakkan" atau bahkan demi gengsi belaka, bayangkan jika pramuniaga peritel tersebut 
bermuka masam dan menatap pengunjung seperti pengganggu yang hanya menambah repot pekerjaan mereka dalam hal merapikan barang. Selain hal tersebut, mungkin yang paling penting adalah penjualan produk lokal, sehingga keuntungan yang diraih tidak hanya milik peritel namun juga dirasakan oleh produsen lokal sehingga semakin meratakan kesenjangan kesejahteraan masyarakat yang selama ini di gadang - gadang sebagai penyebab rendahnya pendapatan perkapita Indonesia, padahal tidak sedikit warga Indonesia yang hidup berlebih walaupun pada kenyataannya lebih banyak lagi yang harus merasakan kesulitan ekonomi dalam hidupnya.

Bila hal diatas dapat dikembangkan oleh peritel dan produsen lokal tentunya dalam kaitan menciptakan produk lokal berkualitas maka tidak hanya sekedar bergulir dan bertahan di pasar yang kian kompetitif, namun industry ritel kemudian juga dapat menopang roda perekonomian nasional dan menguasai pasar di tengah iklim yang kian kompetitif tersebut dan kemudian tentunya peritel tidak harus lagi menggantungkan asanya dalam penyelenggaraan diskon besar-besaran, sebagai konsumen tentu saya masih mengharapkan keberadaan pagelaran diskon besar, namun diskon yang sehat dalam artian saya mendapatkan produk yang masih layak dengan harga dibawah harga normal tanpa terkesan murahan. Ada satu kesimpulan penting dalam makalah ini, yaitu adalah benar bahwa konsumtif itu tidak baik, namun bukan berarti hanya memiliki keburukkan saja, industry ritel Indonesia telah membuktikannya sampai dengan saat ini. Potensi konsumtifnya masyarakat apabila masih dalam tahap normal memiliki sumbangan yang tidak sedikit bagi ritel, meskipun demikian seharusnya hal ini tidak menjadi alasan menjadi masyarakat yang semakin konsumtif dimana anda keluar rumah, berbelanja besar-besaran diluar yang menjadi kebutuhan anda dan kemudian mengatakan anda berbelanja demi menyelematkan perekonomian Indonesia. 


\section{DAFTAR PUSTAKA}

Aritonang R., Lerbin R. 2005. Peramalan Bisnis. Ghalia Indonesia: Jakarta

Berman, B., Evans, J.R. 2007. Retail Management, A Strategic Approach. 10th edition. Pearson Education, Inc., McGraw Hill : New York

Bevly, Ben. 2008. Managing For Profit Organizations in the Flatter World. $1^{\text {st }}$ edition. GPU: Jakarta

Clow, E. Kenneth \& Baack Donald. 2004. Integrated Advertising, Promotion and Marketing Communication. 2nd ed. Pearson Prentice Hall: New Jersey.

Dunne, P.M., Lusch, R.F. 2008. Retailing. 6th edition. Thomson South-Western, Mason : Ohio.

Goldblatt \& Supovitz. 2005. Dollar \& Events. $1^{\text {st }}$ edition. John Wiley \& Sons, Inc.

Hawkins and Mothersbaugh. 2010. Consumer Behaviour, Building Marketing Strategy. $11^{\text {th }}$ edition. McGraw Hill: New York

Kanjaya, Meshvara dan Susilo, Yongki. 2010. Retail Rules. Cetakan Pertama. Penerbit Erlangga : Jakarta

Kotler, Philip, Keller, L. K., Ang, H.S., Leong, M. S, Tan, T.C. 2006. Marketing Management: An Asian Perspective. 4th ed.. McGraw Hill : New York.

Levy, M., Weitz, B.A. 2009. Retailing Management. 7th edition. McGraw-Hill/Irwin :
New York.

Sugiyono. 2006. Metode Penelitian Bisnis. Edisi kesepuluh. Alfabeta: Bandung www.dabenhams.com

www.map-indonesia.com

www.matahari.co.id

www.senayancity.com

www.retailrulebook.com 